\title{
1 Biofilm growth and nitrogen uptake responses to increases in nitrate
}

4 Miquel Ribot ${ }^{1}$, Daniel von Schiller ${ }^{2}$, Francesc Sabater ${ }^{3}$ and Eugènia Martí ${ }^{1}$

5

6 Integrative Freshwater Ecology Group, Centre d'Estudis Avançats de Blanes, (CEAB-

7 CSIC), Accés a la Cala St. Francesc 14, 17300, Blanes, Spain. E-mail:

8 mribot@ceab.csic.es, and eugenia@ceab.csic.es. Tel:+34972336101,

$9 \quad$ Fax:+34972337806

$10{ }^{2}$ Faculty of Science and Technology, University of the Basque Country. PO Box 644,

11 48080, Bilbao, Spain. E-mail: d.vonschiller@ehu.es. Tel: +34946015939

12

24 Keywords: nitrogen, biofilm, uptake, ammonium, nitrate, stream

\section{and ammonium availability}

Diagonal 645, 08028 Barcelona, Spain. E-mail: fsabater@ub.edu. Tel: +34934021516, Fax: +34934111438 


\section{Abstract}

Nitrate $\left(\mathrm{NO}_{3}^{-}\right)$and ammonium $\left(\mathrm{NH}_{4}^{+}\right)$are the two major dissolved inorganic nitrogen

(DIN) species available in streams. Human activities increase stream DIN

concentrations and modify the $\mathrm{NO}_{3}{ }^{-}: \mathrm{NH}_{4}{ }^{+}$ratio. However, few studies have examined

biofilm responses to enrichment of both DIN species. We examined biofilm responses

to variation in ambient concentrations and enrichments in either $\mathrm{NO}_{3}{ }^{-}$or $\mathrm{NH}_{4}{ }^{+}$. We

incubated nutrient diffusing substrata (NDS) bioassays with three treatments (DIN-free, $+\mathrm{NO}_{3}{ }^{-}$and $\left.+\mathrm{NH}_{4}{ }^{+}\right)$in five streams. Biomass-specific uptake rates $\left(\mathrm{U}_{\text {spec }}\right)$ of $\mathrm{NO}_{3}{ }^{-}$and

$\mathrm{NH}_{4}{ }^{+}$were then measured using in situ additions of ${ }^{15} \mathrm{~N}$-labeled $\mathrm{NO}_{3}{ }^{-}$and $\mathrm{NH}_{4}{ }^{+}$.

Biomass (estimated from changes in carbon content) and algal accrual rates, as well as $\mathrm{U}_{\text {spec }}-\mathrm{NO}_{3}{ }^{-}$of biofilms in DIN-free treatments varied among the streams in which the

NDS had been incubated. Higher ambient DIN concentrations were only correlated with enhanced biofilm growth rates. $\mathrm{U}_{\text {spec }}-\mathrm{NO}_{3}{ }^{-}$was one order of magnitude greater and more variable than $\mathrm{U}_{\text {spec }}-\mathrm{NH}_{4}{ }^{+}$, however similar relative preference index (RPI) suggested that biofilms did not show a clear preference for either DIN species. Biofilm growth and DIN uptake in DIN-amended NDS (i.e., $+\mathrm{NO}_{3}{ }^{-}$and $+\mathrm{NH}_{4}{ }^{+}$) were consistently lower than in DIN-free NDS (i.e., control). Lower values in controls with respect to amended NDS were consistently more pronounced for algal accrual rates and $\mathrm{U}_{\text {spec }}-\mathrm{NO}_{3}{ }^{-}$and for the $+\mathrm{NH}_{4}{ }^{+}$than for the $+\mathrm{NO}_{3}{ }^{-}$treatments. In particular, enrichment cycling in high $\mathrm{NH}_{4}{ }^{+}$streams. 
51 Nitrogen $(\mathrm{N})$ is a key element for organisms and its availability can either limit

52 production or favor eutrophication in aquatic ecosystems (Dodds and Welch 2000;

53 Francoeur 2001). Nitrate $\left(\mathrm{NO}_{3}{ }^{-}\right)$and ammonium $\left(\mathrm{NH}_{4}{ }^{+}\right)$are the two major dissolved 54 inorganic nitrogen (DIN) species available in running waters. These two DIN species undergo different biogeochemical pathways and their relative availability may affect DIN fate. In streams, DIN cycling is mostly mediated by the benthic microbial assemblages (bacteria, fungi and algae) that develop on submersed substrata (i.e., biofilms; Pusch et al. 1998; Battin et al. 2003). Microorganisms in biofilms can directly assimilate the two DIN species from the water column. The rates at which they assimilate $\mathrm{NO}_{3}{ }^{-}$and $\mathrm{NH}_{4}{ }^{+}$not only depend on the availability of each single DIN species (Dodds et al. 2002; O'Brien et al. 2007; Ribot et al. 2013), but they are also dependent on the relative availability of the two species (Geisseler et al. 2010; Ribot et al. 2013). In addition, $\mathrm{NH}_{4}{ }^{+}$can be directly incorporated into biomass via anabolic pathways while incorporation of $\mathrm{NO}_{3}{ }^{-}$into the cells requires an active pumping and a further reduction to $\mathrm{NH}_{4}{ }^{+}$; consequently, assimilation of $\mathrm{NO}_{3}{ }^{-}$is an energy-consuming process (McCarty 1995). Therefore, microbial assimilation of $\mathrm{NO}_{3}{ }^{-}$may be induced by the presence of $\mathrm{NO}_{3}{ }^{-}$, and it may be suppressed by the presence of $\mathrm{NH}_{4}{ }^{+}$(Gonzalez et al. 2006). Furthermore, this effect at the biofilm level may have consequences at the ecosystem level as suggested in previous studies (Dugdale et al. 2007; Domingues et al. 2011). Understanding how biofilms respond to increases in $\mathrm{NO}_{3}{ }^{-}$or $\mathrm{NH}_{4}{ }^{+}$is important because human activity increases total DIN availability and changes the relative abundance of the two DIN species (Stanley and Maxted 2008; von Schiller et al. 2008; 
streams draining catchments dominated by agricultural practices have higher

$\mathrm{NO}_{3}{ }^{-}: \mathrm{NH}_{4}{ }^{+}$ratios than streams dominated by urban activity. Conversely, urban streams tend to be $\mathrm{NH}_{4}{ }^{+}$enriched at sites where effluent from wastewater treatment plants are subjected to a partial nitrification of the $\mathrm{N}$ loads received. Studies addressing the effect of increases in DIN availability on the growth of stream biofilms with explicit consideration of the two DIN species (i.e., $\mathrm{NO}_{3}{ }^{-}$and $\mathrm{NH}_{4}{ }^{+}$) are scarce (but see von Schiller et al. 2007 and Hoellein et al. 2010). In addition, results from these studies are contradictory, showing either a preference for $\mathrm{NH}_{4}{ }^{+}$as an $\mathrm{N}$ source for DIN assimilatory uptake (von Schiller et al. 2007) or no differential effect between the two DIN species on biofilm growth (Hoellein et al. 2010). Furthermore, studies designed to compare biofilm uptake responses to increases in $\mathrm{NO}_{3}{ }^{-}$and $\mathrm{NH}_{4}{ }^{+}$concentration have mostly been conducted in the laboratory (Kemp and Dodds 2002; O'Brien and Dodds 2008; Domingues et al. 2011; Bunch and Bernot 2012), with few field experiments (but see Bernot et al. 2006 and Ribot et al. 2013). $\mathrm{NH}_{4}{ }^{+}$has been usually considered the preferred DIN source for DIN uptake (Dortch 1990; Naldi and Wheeler 2002); however, instances when $\mathrm{NO}_{3}{ }^{-}$is the main $\mathrm{N}$ source for microorganisms are common due to the generally greater $\mathrm{NO}_{3}{ }^{-}$availability (Domingues et al. 2011; Bunch and Bernot 2012; Ribot et al. 2013).

The goal of this study was to examine biofilm responses in terms of growth and DIN uptake to variation in ambient concentrations and enrichments of either $\mathrm{NO}_{3}{ }^{-}$or $\mathrm{NH}_{4}{ }^{+}$. We conducted nutrient diffusing substrata (NDS) bioassays with three treatments (DIN-free, $+\mathrm{NO}_{3}{ }^{-}$and $+\mathrm{NH}_{4}{ }^{+}$) in five streams spanning a range in ambient DIN availability. The NDS allowed us to measure biomass and algal growth under the different treatments in the different streams. In addition, at the end of NDS incubations, we exposed the different biofilms developed on the NDS to ${ }^{15} \mathrm{~N}$ additions of either $\mathrm{NO}_{3}{ }^{-}$ 
or $\mathrm{NH}_{4}{ }^{+}$in a single location to measure their capacity for DIN assimilation of the two

species as well as their relative preference for the uptake of the two DIN species.

Comparison of assimilation rates between biofilms under control and DIN amended conditions allowed us to estimate the effect of DIN species enrichments on $\mathrm{N}$ assimilation rates of biofilms. We expected that biofilms in streams with higher ambient DIN concentration would have higher growth rates and higher $\mathrm{N}$ demand (i.e., higher DIN uptake rates) than those developed in low DIN concentrations if biofilms were not limited by any other environmental factor. In addition, we expected that responses of biofilms to $\mathrm{NH}_{4}{ }^{+}$enrichments would be higher than those to $\mathrm{NO}_{3}{ }^{-}$enrichments because of greater energetic cost of $\mathrm{NO}_{3}{ }^{-}$assimilation.

\section{Methods}

\section{Study sites}

La Tordera catchment (Catalonia, NE Spain) has an area of $868.5 \mathrm{~km}^{2}$ dominated by siliceous geology, and covers a 1700-m altitudinal gradient from the headwaters to the sea level within a $35 \mathrm{~km}$ distance. Climate in this region is typically Mediterranean, with warm, dry summers, and mild, humid winters. Although most of the catchment is forested, agricultural, urban and industrial areas tend to concentrate in the river valley, resulting in a heterogeneous land use template along the lowlands of the river network, which affects stream N concentrations (von Schiller et al. 2008). Within this catchment, we selected five streams draining sub-catchments with different land uses. Three sites have forested land-use $99 \%$ of the watersheds, and the other two sites have human land-use (i.e., agriculture + urban) of 2.7 and $7.1 \%$ (Table 1 ) mostly adjacent to the stream. These streams were selected to cover a wide range of DIN concentration based on data from 15 streams in la Tordera catchment collected biweekly from September 
2004-July 2007 (M. Ribot, unpublished data). Santa Fe del Montseny (MON), Font del Regàs (FR) and Castanyet (CAS) are low DIN concentration streams located at headwater-forested catchments. In contrast, Gualba (GUA) and Santa Coloma (COL) are higher DIN concentration streams located at the river valley and influenced by urban (GUA) and agricultural (COL) activities (Table 1).

\section{Experimental approach}

We conducted two separate sets of nutrient diffusing substrata (NDS) bioassays, each one including enrichments of $\mathrm{NO}_{3}{ }^{-}$and $\mathrm{NH}_{4}{ }^{+}$(see description below), in each of the five study streams. After incubation in the stream, all NDS were brought together for measurement of $\mathrm{N}$ assimilation $\left({ }^{15} \mathrm{~N}\right.$ uptake) at a common location. The first set of NDS bioassays started on June 21st 2006 and lasted for 16 days. After the incubation, we replaced the agar solution of all treatments by fresh DIN-free agar solution to ensure biofilm DIN uptake from the water column. These DIN-free NDS were transferred to COL stream in containers filled with stream water. NDS were left in the stream for 5 days prior to the ${ }^{15} \mathrm{NO}_{3}{ }^{-}$addition (see description below) to estimate rates of $\mathrm{NO}_{3}{ }^{-}$ assimilation by all the biofilms. We repeated the procedure for the second set of NDS bioassays, which started on July 7th and lasted for 21 days, with an acclimation period of 4 days before conducting the ${ }^{15} \mathrm{NH}_{4}{ }^{+}$addition (see description below) to estimate rates of $\mathrm{NH}_{4}{ }^{+}$assimilation by all the biofilms. Due to economic and logistic constraints, we could not conduct separate ${ }^{15} \mathrm{~N}$ tracer additions in each study stream to quantify in situ biofilm $\mathrm{NO}_{3}{ }^{-}$and $\mathrm{NH}_{4}{ }^{+}$uptake rates from the biofilm developed on the NDS. We acknowledge that the acclimation period (4-5 days) of all biofilms in the COL stream may have caused some changes in biofilm composition; and thus, in their uptake responses. However, since the acclimatization time was much shorter than the time 
biofilms were exposed to all the DIN treatments in the different streams, we expected this treatment conditions should dictate biofilm responses. In fact, significant differences in biofilm structural and functional parameters were observed among streams (see "Results").

\section{NDS bioassays}

We constructed NDS following the method outlined in Tank and Dodds (2003). The NDS consisted of $60 \mathrm{~mL}$ plastic containers filled with a $2 \%$ (by mass) agar solution, which was not amended (i.e., DIN-free treatments) or was amended either with nitrate $\left(0.5 \mathrm{M} \mathrm{KNO}_{3}\right.$; hereafter referred as $\left.+\mathrm{NO}_{3}{ }^{-}\right)$or ammonium $\left(0.5 \mathrm{M} \mathrm{NH}_{4} \mathrm{Cl}\right.$; hereafter referred as $\left.+\mathrm{NH}_{4}{ }^{+}\right)$. We placed pre-combusted and pre-weighed Whatman GF/F glass fiber filters on the top of the plastic containers to cover the agar completely and to serve as the substrata for biofilm colonization. In each stream we placed three plastic baskets in a single pool. Each plastic basket contained two replicates of each treatment (DINfree, $+\mathrm{NO}_{3}{ }^{-}$and $+\mathrm{NH}_{4}{ }^{+}$) and stream cobbles to hold the baskets on place. Controls were placed upstream to avoid leaching nutrients towards the substratum immediately downstream. We placed the baskets on the streambed of pools of similar water depth and velocity. Stream substratum of all the selected stream reaches was composed of cobbles and pebbles with sand patches. During the study period, a well-developed riparian canopy cover shaded all the selected reaches.

During the two NDS incubation periods, we collected stream water samples on 3 evenly spaced dates for ambient nutrient concentration analyses. We collected water samples with plastic syringes and filtered them immediately through ashed Whatman (Maidstone, UK) GF/F fiber glass filters into acid-washed plastic containers and stored them on ice for transportation to the laboratory until analysis. On the same dates, we 
measured water conductivity and water temperature with a portable WTW conductivity meter (Weilheim, Germany). In addition, we determined discharge on a single crosssectional transect by measuring mean wetted width, mean depth and mean water velocity (Gordon et al. 1992).

\section{${ }^{15} \mathrm{~N}$ constant rate additions}

In COL stream, we selected a $250-\mathrm{m}$ reach to run the two ${ }^{15} \mathrm{~N}$ additions. In this reach, and prior to the ${ }^{15} \mathrm{~N}$ additions, we randomly distributed all NDS from the other four sites along a cross-section located $50 \mathrm{~m}$ downstream of the ${ }^{15} \mathrm{~N}$ addition point. For each ${ }^{15} \mathrm{~N}$ addition (i.e., ${ }^{15} \mathrm{NO}_{3}{ }^{-}$and ${ }^{15} \mathrm{NH}_{4}{ }^{+}$) we prepared a solution amended with either ${ }^{15} \mathrm{NO}_{3}{ }^{-}$ (as $99 \%$ enriched $\mathrm{K}^{15} \mathrm{NO}_{3}$ ) or ${ }^{15} \mathrm{NH}_{4}{ }^{+}$(as $99 \%$ enriched ${ }^{15} \mathrm{NH}_{4} \mathrm{Cl}$ ) in conjunction with $\mathrm{NaCl}$, as a conservative tracer. The amount of $\mathrm{K}^{15} \mathrm{NO}_{3}$ and ${ }^{15} \mathrm{NH}_{4} \mathrm{Cl}$ and the pump flow rate were set to achieve a target $\delta^{15} \mathrm{~N}$ enrichment of $10,000 \%$ for each DIN species in the water column. We released the ${ }^{15} \mathrm{~N}$ solutions at the top of the reach at a constant rate using a Masterflex (Vernon Hills, Illinois, USA) L/S battery-powered peristaltic pump. The two ${ }^{15} \mathrm{~N}$ additions started at midnight (00:00) and lasted for $12 \mathrm{~h}$. The ${ }^{15} \mathrm{NO}_{3}{ }^{-}$ addition was run on July 12th and the ${ }^{15} \mathrm{NH}_{4}{ }^{+}$addition was run on August 1 st.

We collected stream water samples at the NDS location for the analysis of the ${ }^{15} \mathrm{~N}$ isotopic signature of both DIN species $\left({ }^{15} \mathrm{NO}_{3}{ }^{-}\right.$and $\left.{ }^{15} \mathrm{NH}_{4}{ }^{+}\right) 24 \mathrm{~h}$ prior to the start of the ${ }^{15} \mathrm{~N}$ tracer additions and at plateau conditions. To verify plateau conditions during each ${ }^{15} \mathrm{~N}$ addition, we automatically recorded conductivity every $10 \mathrm{~s}$ at the end of the stream reach using a portable WTW conductivity meter connected to a Campbell Scientific (Logan, Utah, USA) data logger. $24 \mathrm{~h}$ after the end of each ${ }^{15} \mathrm{~N}$ addition, coinciding with the water collection described above, we also collected the NDS filters, cut them in half and kept them on ice in the field until further laboratory analyses. 
One half of each filter was oven-dried at $60{ }^{\circ} \mathrm{C}$ until constant weight to estimate biofilm dry mass, $\mathrm{C}$ and $\mathrm{N}$ content and ${ }^{15} \mathrm{~N}$ signature. To estimate the biofilm dry mass we weighed the oven-dried half-filters to the nearest $0.001 \mathrm{mg}$ on a Mettler-Toledo (Greifensee, Switzerland) MX5 microbalance and we subtracted 1/2 of the filter weight. We then encapsulated the half-filters in tins.

The other half of the filter was kept frozen until the measurement of chlorophylla (chla) content following McIntire et al. (1996). We submerged the frozen half-filters in a known volume of $90 \% \mathrm{v} / \mathrm{v}$ acetone and kept them in the dark at $4{ }^{\circ} \mathrm{C}$ overnight. We then sonicated the filters for $5 \mathrm{~min}$ and centrifuged them for $10 \mathrm{~min}$ at $4000 \mathrm{rpm}$. We measured the absorbance of the resultant supernatant at 664, 665 and $750 \mathrm{~nm}$ before and after acidification using a Shimadzu (Tokyo, Japan) UV spectrometer. We analyzed water samples for the concentrations of $\mathrm{NO}_{3}{ }^{-}, \mathrm{NH}_{4}{ }^{+}$, and soluble reactive phosphorus (SRP) on a Bran + Luebbe (Norderstedt, Germany) TRAACS 2000 autoanalyzer following standard colorimetric methods (APHA 1995). We processed amended a known volume of sample with $3 \mathrm{~g} \mathrm{~L}^{-1}$ of $\mathrm{MgO}$ and $50 \mathrm{~g} \mathrm{~L}^{-1}$ of $\mathrm{NaCl}$ and a Teflon filter packet containing an acidified 1-cm-diameter ashed Whatman GF/D fiber glass filter to trap the volatilized $\mathrm{NH}_{3}$, and incubated it on a shaker at $40{ }^{\circ} \mathrm{C}$ for 4 weeks. For ${ }^{15} \mathrm{NO}_{3}{ }^{-}$determination, we amended a known volume of the sample with $3 \mathrm{~g}$ of $\mathrm{MgO}$ and $5 \mathrm{~g}$ of $\mathrm{NaCl}$ and boiled it to remove the $\mathrm{NH}_{4}{ }^{+}$. We then added $0.5 \mathrm{mg}$ of $\mathrm{MgO}$ and $0.5 \mathrm{mg}$ Devarda's alloy to reduce the $\mathrm{NO}_{3}{ }^{-}$to $\mathrm{NH}_{4}{ }^{+}$, and treated the remaining sample as for ${ }^{15} \mathrm{NH}_{4}{ }^{+}$. We also diffused a set of standards of known volume for volume-related fractionation corrections. Once the incubation was completed, we removed the filter 
packets and placed them in a desiccator for 4 days. We then encapsulated the filters in tins and stored them until ${ }^{15} \mathrm{~N}$ analysis.

Samples for the determination of the ${ }^{15} \mathrm{~N}$ signature were analyzed at the University of California Stable Isotope Facility (Davis, California, USA). The C and N content (as a percentage of dry mass) and the abundance of the heavier isotope, expressed as the ${ }^{15} \mathrm{~N}:{ }^{14} \mathrm{~N}$ ratio compared to that of a standard (i.e., $\mathrm{N}_{2}$ from the atmosphere) using the notation of $\delta^{15} \mathrm{~N}$ in units of $\%$, were measured by continuousflow isotope-ratio mass spectrometry (20-20 mass spectrometer; PDZ Europa, Northwich, UK) after sample combustion in an on-line elemental analyzer (PDZ Europa ANCA-GSL).

\section{Parameter calculations}

For each NDS treatment and stream, biomass accrual rates (in $\mu \mathrm{g} \mathrm{C} \mathrm{cm}^{-2} \mathrm{~d}^{-1}$ ) were calculated by dividing the $\mathrm{C}$ content (in $\mu \mathrm{g} \mathrm{C} \mathrm{cm}^{-2}$ ) at the end the of the NDS incubation by the time period of the incubation (in days). Similarly, the algal accrual rates (in $\mu \mathrm{g}$ chla $\mathrm{cm}^{-2} \mathrm{~d}^{-1}$ ) were calculated by dividing the chla content (in $\mu \mathrm{g}$ chla $\mathrm{cm}^{-2}$ ) at the end the of the NDS incubation by the time period of the incubation (in days). We also calculated the $\mathrm{C}$ to $\mathrm{N}$ molar ratio of the biofilms at the end of the NDS incubation based on the percentage of $\mathrm{C}$ and $\mathrm{N}$ in dry mass. To calculate biofilm DIN uptake rates of $\mathrm{NO}_{3}{ }^{-}$and $\mathrm{NH}_{4}{ }^{+}$from the ${ }^{15} \mathrm{NO}_{3}$ and ${ }^{15} \mathrm{NH}_{4}$ additions, respectively, we first calculated the amount of ${ }^{15} \mathrm{~N}$ tracer contained in biofilm biomass $\left({ }^{15} \mathrm{~N}_{\text {biofilm}}\right.$; in $\left.\mu \mathrm{g} \mathrm{N} \mathrm{m}^{-2}\right)$ at the end of the addition using the following equation:

$$
{ }^{15} \text { Nbiofilm }=\text { Bbiofilm } \times N / 100 \times\left(M F_{i}-M F b\right)
$$


where $\mathrm{B}_{\text {biofilm }}$ is the biofilm as dry mass per unit of area $\left(\mu \mathrm{g} \mathrm{m}^{-2}\right), \mathrm{N}$ is the biofilm $\mathrm{N}$ content expressed as percentage of dry mass, MF is the molar fraction of ${ }^{15} \mathrm{~N}$ in biofilm at plateau conditions $\left(\mathrm{MF}_{\mathrm{i}}\right)$ and at background conditions $\left(\mathrm{MF}_{\mathrm{b}}\right)$.

We then estimated the DIN uptake rate $\left(\mathrm{U}\right.$; in $\left.\mu \mathrm{g} \mathrm{N} \mathrm{m}{ }^{-2} \mathrm{~s}^{-1}\right)$ for either $\mathrm{NO}_{3}{ }^{-}$or $\mathrm{NH}_{4}{ }^{+}$using the following equation:

$$
U={ }^{15} \text { Nbiofilm } / \text { Taddition } \times\left({ }^{15} N \text { flux } / N \text { flux }\right)
$$

where ${ }^{15} \mathrm{~N}_{\text {biofilm }}$ is the amount of ${ }^{15} \mathrm{~N}$ tracer in biofilm biomass from Eq. (1), $\mathrm{T}_{\text {addition }}$ is the duration of the ${ }^{15} \mathrm{~N}$ addition $(12 \mathrm{~h}),{ }^{15} \mathrm{~N}_{\text {flux }}$ is the stream water ${ }^{15} \mathrm{~N}$ flux (as either $\mathrm{NO}_{3}{ }^{-}$or $\mathrm{NH}_{4}{ }^{+}$) at plateau conditions $\left(\mu \mathrm{g}{ }^{15} \mathrm{~N} \mathrm{~s}^{-1}\right.$ ) and $\mathrm{N}_{\text {flux }}$ is the total $\mathrm{N}$ flux (as either $\mathrm{NO}_{3}{ }^{-}$or $\left.\mathrm{NH}_{4}{ }^{+}\right)$based on stream water concentration and discharge $\left(\mu \mathrm{g} \mathrm{N} \mathrm{s}{ }^{-1}\right)$. For each DIN species, we calculated the biomass-specific DIN uptake rate $\left(\mathrm{U}_{\mathrm{spec}} ; \mathrm{s}^{-1}\right)$ by diving $\mathrm{U}$ by the $\mathrm{N}$ content in biofilm biomass. We used $\mathrm{U}_{\text {spec }}$ over $\mathrm{U}$ to compare uptake responses among streams and NDS treatments because it avoids confounding effects associated with differences in $\mathrm{N}$ biomass accrual rates among all treatments. $\mathrm{U}_{\text {spec }}$ has been used in the literature as an indicator of $\mathrm{N}$ turnover time within a biotic compartment (Dodds et al. 2004).

To assess the biofilm uptake preference for either $\mathrm{NO}_{3}{ }^{-}$or $\mathrm{NH}_{4}{ }^{+}$, we calculated the relative preference index (RPI) for $\mathrm{NO}_{3}{ }^{-}$as proposed by Dortch (1990) using the equation:

$$
\mathrm{RPINO}_{3}=\left(\mathrm{UNO}_{3} / \Sigma U \mathrm{DIN}\right) /\left(\mathrm{NO}_{3} / \mathrm{DIN}\right)
$$

where $U_{N O_{3}}$ is the biofilm $\mathrm{NO}_{3}{ }^{-}$uptake rate ( $\mathrm{U}_{\text {for }} \mathrm{NO}_{3}{ }^{-}$from Eq. 2; in $\mu \mathrm{g} \mathrm{N} \mathrm{m}^{-2} \mathrm{~s}^{-1}$ ) in a given NDS filter, $\Sigma \mathrm{UDIN}_{\text {in }}$ is the sum of the mean biofilm uptake rate of $\mathrm{NO}_{3}{ }^{-}$and $\mathrm{NH}_{4}{ }^{+}$ ( $\mathrm{U}$ for $\mathrm{NH}_{4}{ }^{+}$from Eq. 2 ; in $\mu \mathrm{g} \mathrm{N} \mathrm{m}^{-2} \mathrm{~s}^{-1}$ ) within a NDS treatment, $\mathrm{NO}_{3}$ is the mean nitrate concentration in COL during the two ${ }^{15} \mathrm{~N}$ additions and DIN is the sum of the mean concentrations of $\mathrm{NH}_{4}{ }^{+}$and $\mathrm{NO}_{3}{ }^{-}$in $\mathrm{COL}$ during the two ${ }^{15} \mathrm{~N}$ additions. RPI is an 
274 indicator of the relevance of $\mathrm{NO}_{3}{ }^{-}$uptake relative to total DIN uptake weighed by the

275 relative importance of $\mathrm{NO}_{3}{ }^{-}$concentration to total DIN concentration. For example if

$276 \mathrm{NO}_{3}{ }^{-}$uptake is $50 \%$ of DIN uptake, but $\mathrm{NO}_{3}{ }^{-}$is only $25 \%$ of DIN, the RPI value is

$2770.5 / 0.25=2$, indicating preference for $\mathrm{NO}_{3}{ }^{-}$given the available DIN species. An RPI-

$278 \mathrm{NO}_{3}{ }^{-}$value $<1$ indicates a preference for $\mathrm{NH}_{4}{ }^{+}$.

279 To explore the biofilm response in terms of biomass accrual, algal accrual, C:N

280 ratios and uptake rates of the two DIN species to the enrichments of $\mathrm{NO}_{3}{ }^{-}$or $\mathrm{NH}_{4}{ }^{+}$, we

281 calculated the response ratio to each DIN species as described in Tank and Dodds

282 (2003). For each variable, we calculated the logarithmic ratio of the values from

283 amended treatments $\left(+\mathrm{NO}_{3}{ }^{-}\right.$or $\left.+\mathrm{NH}_{4}{ }^{+}\right)$relative to the control treatment (DIN-free).

284 Response ratios (RRs) can be positive (i.e., treatment values greater than control) or negative (i.e., treatment values lower than control). The RR allows normalizing for the varying effect of NDS treatments on biofilm growth and DIN uptake rates among streams and among replicate locations within each stream, which may mask any treatment effects on areal uptake.

\section{Statistical analyses}

We pooled the data from control treatments (DIN-free) from the two NDS incubations to explore differences in biofilm growth at ambient concentrations among streams in which the NDS were incubated. We compared biomass and algal accrual rates and C:N molar ratios using a linear mixed-effects model with stream as fixed factor $(n=5)$ and incubation date as random factor $(\mathrm{n}=2)$. We included the random effect 'incubation date' in the model to account for the potential temporal variation in biofilm responses between the two sets of NDS bioassays, despite initial analysis indicated that this effect was negligible. However, the inclusion of a non-significant random effect factor does 
not influence the inference on fixed effects factors (Zuur et al. 2009). On the other hand, since $\mathrm{U}_{\text {spec }}-\mathrm{NO}_{3}{ }^{-}$and $\mathrm{U}_{\text {spec }}-\mathrm{NH}_{4}{ }^{+}$for control treatments were calculated separately from the first and the second NDS incubations respectively, we compared $\mathrm{U}_{\text {spec }}-\mathrm{NO}_{3}{ }^{-}, \mathrm{U}_{\text {spec }}{ }^{-}$ $\mathrm{NH}_{4}{ }^{+}$and RPI using one-way ANOVA with stream as fixed factor $(\mathrm{n}=5)$ to explore differences in these variables at ambient concentrations among streams in which the NDS were incubated. We explored biofilm growth response to enrichments of $\mathrm{NO}_{3}{ }^{-}$or $\mathrm{NH}_{4}{ }^{+}$among streams by comparing the RRs of biomass and algal accrual rates and C:N molar ratios using a linear mixed-effects model with stream $(n=5)$ and NDS treatment $(n=2)$ as fixed factors and incubation as random factor $(n=2)$. Again, we included the random effect of 'incubation date' in the model, despite this random effect was shown to be negligible. To explore biofilm DIN uptake response to enrichments of either $\mathrm{NO}_{3}{ }^{-}$or $\mathrm{NH}_{4}{ }^{+}$among streams, we compared the RRs of $\mathrm{U}_{\text {spec }}-\mathrm{NO}_{3}{ }^{-}, \mathrm{U}_{\text {spec }}-\mathrm{NH}_{4}{ }^{+}$and RPI using two-way ANOVA with stream $(n=5)$ and NDS treatment $(n=2)$ as fixed factors. followed significant fixed factor $(\mathrm{p}<0.05)$ using the R package 'multcomp'. Post-hoc 
log-transformed before analysis to meet assumptions of homogeneity of variance and normality (Zar 1996).

\section{Results}

\section{Physical and chemical characteristics of the study streams}

During the study period, mean discharge was relatively low at all streams and averaged

9.6 $\mathrm{L} \mathrm{s}^{-1}$ (Table 1). Stream water temperature and conductivity ranged from 14.2 to $21.4{ }^{\circ} \mathrm{C}$ and 61 to $310 \mu \mathrm{S} \mathrm{cm}^{-1}$, respectively, across streams. Concentration of $\mathrm{NH}_{4}{ }^{+}$ was low and relatively similar among streams, ranging from 14 to $22 \mu \mathrm{g} \mathrm{N} \mathrm{L}^{-1}$. In contrast, $\mathrm{NO}_{3}{ }^{-}$concentration ranged from 140 to $600 \mu \mathrm{g} \mathrm{N} \mathrm{L}{ }^{-1}$, and SRP concentrations ranged from 4 to $46 \mu \mathrm{g} \mathrm{P} \mathrm{L}{ }^{-1}$ (Table 1). The lowest $\mathrm{NO}_{3}{ }^{-}$and SRP concentrations were observed in two of the forested streams (CAS and FR), whereas the highest concentrations were observed in COL, the stream with the highest percentage of agricultural land use in the drainage area. As a result of the high variability in nutrient concentrations, we observed a wide range in the $\mathrm{NO}_{3}{ }^{-} \mathrm{NH}_{4}{ }^{+}$ratio (from 8 to 27 ) and in the DIN:SRP molar ratio (23 to 95; Table 1).

\section{Biofilm responses to ambient DIN variability}

Mean biomass accrual rates of biofilms in DIN-free treatments ranged from 43 to $126 \mu \mathrm{g} \mathrm{C} \mathrm{cm}^{-2} \mathrm{~d}^{-1}$, and differed significantly among the streams (Fig. 1a; Table 2) with significant differences between GUA and FR (Tukey HSD tests, $\mathrm{p}<0.020$; Fig. 1a). The biomass accrual rates of biofilms in DIN-free treatments were positively correlated with ambient $\mathrm{NO}_{3}{ }^{-}$concentration $(\mathrm{r}=0.30, \mathrm{p}=0.029$; Fig. $2 \mathrm{a})$ and $\mathrm{NH}_{4}{ }^{+}$concentration $(\mathrm{r}=0.41, \mathrm{p}=0.002 ;$ Fig. $2 \mathrm{~b})$ among streams. Algal accrual rates of biofilms in DIN-free treatments were similar among streams, except in CAS where rates were 5 times greater 
(Tukey HSD tests, $\mathrm{p}<0.001$; Fig. 1b; Table 2). Algal accrual rates of biofilms in DINfree treatments were positively correlated with ambient $\mathrm{NH}_{4}{ }^{+}$concentration among streams $(r=0.31, p=0.023$; Fig. 2d). Furthermore, algal accrual rates of biofilms in DIN-free treatments were positively correlated with biomass accrual rates in the same treatments $(\mathrm{r}=0.38, \mathrm{p}=0.005$; data not shown). The $\mathrm{C}: \mathrm{N}$ molar ratios of biofilms in DIN-free treatments $($ mean $=8.9)$ did not differ significantly among the streams (Fig. 1c; Table 2). $\mathrm{U}_{\text {spec }}-\mathrm{NO}_{3}{ }^{-}$of biofilms in DIN-free treatments was one order of magnitude greater $\left(\right.$ mean $=0.04 \mathrm{~h}^{-1}$ vs. mean $\left.=0.005 \mathrm{~h}^{-1}\right)$ and more variable $(\mathrm{CV}=71 \% \mathrm{vs}$ $\mathrm{CV}=26 \%)$ than $\mathrm{U}_{\text {spec }}-\mathrm{NH}_{4}{ }^{+}$(Fig. 3a, b). $\mathrm{U}_{\text {spec }}-\mathrm{NO}_{3}{ }^{-}$of biofilms in DIN-free treatments varied significantly depending on the stream in which the NDS were incubated (oneway ANOVA, $\left.\mathrm{F}_{4,25}=7.40, \mathrm{p}<0.001\right) . \mathrm{U}_{\text {spec }}-\mathrm{NO}_{3}{ }^{-}$was highest in biofilms developed in MON, and FR (Tukey HSD tests, $\mathrm{p}<0.012$ ). Conversely, $\mathrm{U}_{\text {spec }}-\mathrm{NH}_{4}{ }^{+}$of biofilms in DIN-free treatments did not differ significantly among the streams (one-way ANOVA, $\left.\mathrm{F}_{4,20}=1.66, \mathrm{p}=0.224\right) . \mathrm{U}_{\text {spec }}-\mathrm{NO}_{3}{ }^{-}$of biofilms in DIN-free treatments was negatively correlated with the ambient $\mathrm{NH}_{4}{ }^{+}$concentration of the streams $(\mathrm{r}=-0.37$ and $\mathrm{p}=0.045$; Fig. 2f). Furthermore, $\mathrm{U}_{\text {spec }}-\mathrm{NO}_{3}{ }^{-}$of biofilms in DIN-free treatments was negatively correlated with algal accrual rates in the same NDS treatments $(r=-0.37$ and $p=0.046$; data not shown). among biofilms developed in the different streams (one-way ANOVA, $\mathrm{F}_{4,25}=0.54$, $p=0.712$ ), indicating no clear preference for any of the two DIN species (Fig. 3c). 


\section{Biofilm responses to $\mathrm{NO}_{3}{ }^{-}$and $\mathrm{NH}_{4}{ }^{+}$enrichments}

374 In general, the comparison between DIN-free and DIN-enriched NDS treatments (i.e., 375 the response ratio, RR) showed that both biofilm growth and DIN uptake had no effect or a negative response to $\mathrm{NO}_{3}{ }^{-}$and $\mathrm{NH}_{4}{ }^{+}$enrichments (Figs. 4, 5). The RRs of biomass accrual rates differed significantly among streams (Fig. 4a; Table 3), but they did not differ significantly between $+\mathrm{NO}_{3}{ }^{-}$and $+\mathrm{NH}_{4}{ }^{+}$treatments (Fig. 4a). Biomass accrual response to DIN enrichments was null in those streams with lower DIN ambient availability and most negative in biofilms developed in COL, the stream with the highest DIN (Tukey HSD tests, $\mathrm{p}<0.036$ ). In addition, the RRs of biomass accrual rates in $+\mathrm{NO}_{3}{ }^{-}$treatments were negatively correlated with ambient $\mathrm{NO}_{3}{ }^{-}(\mathrm{r}=-0.39$, $\mathrm{p}=0.004)$ and $\mathrm{NH}_{4}{ }^{+}$concentrations among streams $(\mathrm{r}=-0.38, \mathrm{p}=0.004$; data not shown). The RRs of biofilm accrual rates in $+\mathrm{NH}_{4}{ }^{+}$treatments were also negatively correlated with the ambient $\mathrm{NO}_{3}{ }^{-}$concentration among streams $(\mathrm{r}=-0.34$ and $\mathrm{p}=0.022$ ). These correlations suggest that biomass responsiveness decreased with rising DIN concentration among streams.

The RRs of algal accrual rates in biofilms differed significantly among the streams and between $+\mathrm{NO}_{3}{ }^{-}$and $+\mathrm{NH}_{4}{ }^{+}$treatments (Fig. $4 \mathrm{~b}$; Table 3). The RRs for the two DIN enrichment treatments were negative in the biofilms developed in the three streams with intermediate ambient DIN concentrations (Tukey HSD tests, $\mathrm{p}<0.030$; Fig. 4b) and null in the two streams located in the extremes of the DIN gradient (Tukey HSD tests, $p<0.005 ;$ Fig. 4b). On average, the RRs of algal accrual rates were significantly more negative in $+\mathrm{NH}_{4}{ }^{+}$than in $+\mathrm{NO}_{3}{ }^{-}$treatments (mean $=-0.42$ and -0.09 , respectively; Fig. 4b; Table 3). The RRs of algal accrual rates for both $+\mathrm{NO}_{3}{ }^{-}$ and $+\mathrm{NH}_{4}{ }^{+}$treatments were not correlated with either ambient $\mathrm{NO}_{3}{ }^{-}$or $\mathrm{NH}_{4}{ }^{+}$ concentration among streams. 
The RRs of the biofilm C:N molar ratio were consistently negative across the streams and for both $+\mathrm{NH}_{4}{ }^{+}$and $+\mathrm{NO}_{3}{ }^{-}$treatments. Thus, biofilms exposed to DIN enrichments increased their $\mathrm{N}$ content relative to their $\mathrm{C}$ content. Differences in RRs of $\mathrm{C}: \mathrm{N}$ were significant among streams, but not between $+\mathrm{NO}_{3}{ }^{-}$and $+\mathrm{NH}_{4}{ }^{+}$treatments (Fig. 4c; Table 3). The responses to DIN enrichments were more negative in biofilms developed in GUA (Tukey HSD tests, $\mathrm{p}<0.005$ ).

The RRs of $\mathrm{U}_{\text {spec }}-\mathrm{NO}_{3}{ }^{-}$for biofilms and DIN species enrichments differed significantly depending on the stream in which the biofilms had developed and between $+\mathrm{NO}_{3}{ }^{-}$and $+\mathrm{NH}_{4}{ }^{+}$treatments (Fig. 5a; Table 4). The interaction between the two factors was also significant (Table 4). The reason for the interaction was the $\mathrm{RR}$ of $\mathrm{U}_{\text {spec }}-\mathrm{NO}_{3}{ }^{-}$ was null in biofilms grown in $+\mathrm{NO}_{3}{ }^{-}$treatments and particularly negative for biofilms grown in $+\mathrm{NH}_{4}{ }^{+}$treatments in 4 of the 5 sites (Fig. 5a). However, the pattern was different in GUA. Overall patterns suggest lower biomass-specific uptake of $\mathrm{NO}_{3}{ }^{-}$when biofilms are exposed to $\mathrm{NH}_{4}{ }^{+}$enrichment.

The RRs of $\mathrm{U}_{\text {spec }}-\mathrm{NH}_{4}{ }^{+}$for biofilms developed in different streams and DIN species enrichments were similar regardless of the stream considered and the NDS treatment at which they developed (Fig. 5b; Table 4). In general, the RRs of $\mathrm{U}_{\text {spec- }} \mathrm{NH}_{4}^{+}$ were negative, but lower than the RRs of $\mathrm{U}_{\text {spec }}-\mathrm{NO}_{3}{ }^{-}$, indicating a lower effect of DIN enrichments on $\mathrm{U}_{\text {spec }}-\mathrm{NH}_{4}{ }^{+}$than on $\mathrm{U}_{\text {spec }}-\mathrm{NO}_{3}{ }^{-}$.

The RRs of biofilm RPI differed significantly depending on the stream in which the NDS were incubated and between $+\mathrm{NO}_{3}{ }^{-}$and $+\mathrm{NH}_{4}{ }^{+}$treatments, with no significant interaction between factors (Fig. 5c; Table 4). The exceptions were COL (both solutes) and CAS $\left(\mathrm{NH}_{4}{ }^{+}\right)$. However, despite these differences, the RRs of RPI were not different from 0 in 7 out of 10 cases (Fig. 5c), indicating no overall preference for any of the two DIN species. 


\section{Discussion}

\section{Biofilm responses to ambient DIN variability}

425

426

427

We expected that differences in ambient $\mathrm{NO}_{3}{ }^{-}$and $\mathrm{NH}_{4}{ }^{+}$concentrations among the streams in which the NDS were incubated would affect biofilm development and its N demand from the water column. Specifically, we expected that biofilm growth and DIN uptake would be greater in those biofilms that had developed in streams with higher ambient DIN availability (Dodds et al. 2002; O'Brien et al. 2007; von Schiller et al. 2007; O'Brien and Dodds 2008). We observed that streams with higher ambient $\mathrm{NO}_{3}{ }^{-}$ and $\mathrm{NH}_{4}{ }^{+}$concentrations showed greater biofilm biomass and algal accrual rates, supporting our expectations and suggesting that biofilms development and its contribution to stream water DIN uptake is enhanced under higher availability of DIN. In addition, DIN was below saturating levels and biofilms were likely not limited by other factors. On the other hand, lack of significant variation in the biofilm C:N ratios at ambient levels suggests that the range of ambient DIN concentration was not broad enough to cause significant stoichiometric differences in the biofilms among the studied streams (Dodds et al. 2004).

Biofilm $\mathrm{U}_{\text {spec }}-\mathrm{NO}_{3}{ }^{-}$was consistently greater than $\mathrm{U}_{\text {spec }}-\mathrm{NH}_{4}{ }^{+}$regardless of the differences in the concentrations of the two DIN species among the study streams, suggesting that biofilms have a consistently higher reliance on $\mathrm{NO}_{3}{ }^{-}$than on $\mathrm{NH}_{4}{ }^{+}$from the water column to meet their $\mathrm{N}$ requirements. Our results are in line with previous studies showing that the generally higher $\mathrm{NO}_{3}{ }^{-}$availability as a DIN source ultimately drives the use of this DIN species by biofilms to meet their $\mathrm{N}$ demand (Fellows et al. 2006; Newbold et al. 2006; Bunch and Bernot 2012). RPI values close to 1, indicating no preference for either DIN species, support this explanation. These results contrast the general idea that microbial assemblages in biofilms preferentially remove $\mathrm{NH}_{4}{ }^{+}$due to 
the lower energetic cost (Dortch 1990; Naldi and Wheeler 2002). However, the results are in line with empirical data from a previous study which showed an unclear pattern of biofilm preference for $\mathrm{NH}_{4}{ }^{+}$relative to $\mathrm{NO}_{3}{ }^{-}$availability (Hoellein et al. 2010). expected that variability in $U_{\text {spec }}$ of the two DIN species among biofilms would be positively related to differences in ambient DIN concentration of the streams in which the NDS were previously incubated. However, the results did not support our expectations. Greater $\mathrm{U}_{\text {spec }}-\mathrm{NO}_{3}{ }^{-}$was observed in biofilms that developed in 2 of the 3 streams with the lowest $\mathrm{NO}_{3}{ }^{-}$concentrations, and no differences among streams in biofilm $\mathrm{U}_{\text {spec }}-\mathrm{NH}_{4}{ }^{+}$were found. In fact, we observed lower biofilm $\mathrm{U}_{\text {spec }}-\mathrm{NO}_{3}{ }^{-}$in streams with higher $\mathrm{NH}_{4}{ }^{+}$concentration, which supports previous studies indicating that $\mathrm{NH}_{4}{ }^{+}$availability may regulate the uptake of DIN in the form of $\mathrm{NO}_{3}{ }^{-}$(Gonzalez et al. 2006; Dugdale et al. 2007; Domingues et al. 2011). The low range of variation in $\mathrm{NH}_{4}^{+}$ concentration among streams where biofilms developed (from 14 to $22 \mu \mathrm{g} \mathrm{N} / \mathrm{L}$ ) may have precluded observing differences in $\mathrm{U}_{\text {spec }}-\mathrm{NH}_{4}{ }^{+}$, despite previous studies have shown that a broader range in the concentration of $\mathrm{NH}_{4}{ }^{+}$can control $\mathrm{NH}_{4}{ }^{+}$uptake rates at whole-reach scale (Dodds et al. 2002; O'Brien and Dodds 2008). Alternatively, lack of $\mathrm{U}_{\text {spec }}-\mathrm{NH}_{4}{ }^{+}$variation among biofilms developed in the different streams also suggests that biofilms $\mathrm{NH}_{4}{ }^{+}$turnover was similar among streams, regardless of the differences in biomass accrual and algal growth observed, probably due to the lower range of $\mathrm{NH}_{4}{ }^{+}$ concentration among streams.

471 this context, the negative correlation between algal accrual rates and $\mathrm{U}_{\text {spec }}-\mathrm{NO}_{3}{ }^{-}$, contrasts with other studies indicating that algae in biofilms rely mostly on $\mathrm{NO}_{3}{ }^{-}$ 
473 (Bernhardt et al. 2002; Bechtold et al. 2012). It is worth noting that the streams where

474 the NDS were incubated were heavily shaded by riparian vegetation, which may have

475 limited N demand, especially by algae in biofilms (Hill et al. 1995; Sabater et al. 2000; von Schiller et al. 2007). Therefore, it is possible that light-limitation may have masked

477 the effects of other factors such as variation in DIN concentration or relative availability 478 between DIN and SRP among streams, on algal uptake (von Schiller et al. 2007).

\section{Biofilm responses to enrichments in $\mathrm{NO}_{3}{ }^{-}$or $\mathrm{NH}_{4}{ }^{+}$}

We expected a positive response of biofilms to $\mathrm{NO}_{3}{ }^{-}$and $\mathrm{NH}_{4}{ }^{+}$enrichments if these

DIN species were below saturation under ambient conditions within each stream and if other environmental conditions were favorable. In addition, we expected that the biofilm responses would be more positively pronounced for $\mathrm{NH}_{4}{ }^{+}$than for $\mathrm{NO}_{3}{ }^{-}$ enrichments because biofilms have a higher preference for the former DIN species. However, we found that biofilm response to either $\mathrm{NO}_{3}{ }^{-}$or $\mathrm{NH}_{4}{ }^{+}$enrichments was in general either null or negative for most of the investigated variables, suggesting that biofilms were either above DIN saturation at the ambient conditions at which they developed or that the experimental enrichments affected the structure or the species composition of the biofilms leading to lower biomass accrual rates. Furthermore, algal accrual, $\mathrm{U}_{\text {spec }}-\mathrm{NO}_{3}{ }^{-}$and RPI response ratios were consistently more negative in those The negative response to DIN enrichments was more pronounced for algal accrual than for bulk biomass accrual. This may be explained by the low light availability (i.e., closed canopy reaches) during the experiments, which had a higher 
constrain on algal development in biofilms than on whole-bulk biofilm biomass.

Interestingly, we also observed that the negative responses of algal growth were more pronounced in $+\mathrm{NH}_{4}{ }^{+}$than in $+\mathrm{NO}_{3}{ }^{-}$treatments. Instances of lower biofilm and algal growth in DIN-enriched substrates with respect to control treatments are relatively common in the literature (Francoeur 2001; Tank and Dodds 2003; Bernhardt and Likens 2004; von Schiller et al. 2007), although these studies have mainly focussed on $\mathrm{NO}_{3}{ }^{-}$ enrichments. Several mechanisms have been proposed to explain this response: (1) preference of grazing invertebrates for biofilms developed on nutrient-rich substrates, (2) nutrient enrichment up to toxic levels, or (3) changes in the species composition of biofilms (Bernhardt and Likens 2004; Hoellein et al. 2010; Domingues et al. 2011). Despite field observations during both NDS incubations confirmed low presence of grazers on NDS filters, we cannot rule out invertebrates as responsible for differences in biomass accrual between control and DIN-enriched substrates (Steinman 1996). Furthermore, we cannot exclude the fact that $+\mathrm{NH}_{4}{ }^{+}$treatments lead to toxic effects (Camargo and Alonso 2006) or that either $\mathrm{NO}_{3}{ }^{-}$or $\mathrm{NH}_{4}{ }^{+}$enrichments lead to changes in biofilm assemblage composition because the experiment was not aimed to provide these mechanistic results. Future research could explore the possible toxic effect of $\mathrm{NH}_{4}{ }^{+}$ enrichments by exploring responses using NDS across streams with a wider gradient of ambient $\mathrm{NH}_{4}{ }^{+}$concentrations. observed for $\mathrm{N}$ uptake. In absolute terms, the negative response observed was greater

519 for $\mathrm{U}_{\text {spec }}-\mathrm{NO}_{3}{ }^{-}$than for $\mathrm{U}_{\text {spec }}-\mathrm{NH}_{4}{ }^{+}$and mostly associated with $\mathrm{NH}_{4}{ }^{+}$enrichments. $\mathrm{NO}_{3}{ }^{-}$ enrichment caused only minor changes in either $\mathrm{U}_{\text {spec }}-\mathrm{NO}_{3}{ }^{-}$or $\mathrm{U}_{\text {spec }}-\mathrm{NH}_{4}{ }^{+}$when compared with $\mathrm{NH}_{4}{ }^{+}$enrichment. Based on our results, we suggest that biofilm 
523 the biofilms resulting in a lower demand for $\mathrm{NO}_{3}{ }^{-}$. In addition, $\mathrm{NH}_{4}{ }^{+}$enrichments might

524 have enhanced $\mathrm{NH}_{4}{ }^{+}$sorption and internal $\mathrm{N}$ cycling within the biofilms; thereby

525 decreasing the biofilm $\mathrm{NO}_{3}{ }^{-}$dependence from the water column (von Schiller et al.

526 2007). An alternative explanation is that the enrichment of $\mathrm{NH}_{4}^{+}$can favor the

527 development of nitrifiers, which is supported by results from previous studies

528 (Bernhardt and Likens 2004; Merbt et al. 2014). Nitrifying microorganisms have lower

529 growth efficiencies compared to other microbial components of the biofilms (Risgaard-

530 Petersen et al. 2004) and they also have a preferential demand for $\mathrm{NH}_{4}{ }^{+}$. This potential

531 shift in the microbial composition of biofilms could at least partially explain the more

532 negative effects on $\mathrm{U}_{\text {spec }}-\mathrm{NO}_{3}{ }^{-}$in $\mathrm{NH}_{4}{ }^{+}$enrichments consistently observed for biofilms

533 developed in all streams studied. Future studies following $\mathrm{NH}_{4}{ }^{+}$enrichment in NDS

534 would benefit from measurements of nitrification activity or community composition to 535 elucidate the underlying mechanism driving the observed biofilm response.

536

\section{Conclusions}

538 NDS bioassays have been commonly used to assess nutrient limitation of $\mathrm{P}$ and $\mathrm{N}$ in a

539 large variety of freshwater environments (Francoeur 2001; Johnson et al. 2009; Keck

540 and Lepori 2012; King et al. 2014). However, NDS have rarely been employed to

541 address other ecologically relevant questions, such as to contrast biofilm responses to

542 different DIN species (but see von Schiller et al. 2007 and Hoellein et al. 2010). In

543 addition, studies using NDS have mostly focused on the biofilm response in terms of

544 biomass accrual, and less attention has been paid on how the nutrient enrichments affect

545 biofilm function, such as the demand of nutrients from the water column. In this regard,

546 we found that the most relevant biofilm responses to enrichment of the two DIN species

547 were observed for $\mathrm{N}$ uptake, and more specifically, that $\mathrm{NH}_{4}{ }^{+}$enrichments caused a 
548 clear decrease in $\mathrm{U}_{\text {spec }}-\mathrm{NO}_{3}{ }^{-}$. Knowledge on these responses provides a better

549 understanding of the effects of elevated DIN availability on biofilm development and

550 contribution to in-stream $\mathrm{N}$ uptake. We suggest that biofilms developing in streams with

551 high $\mathrm{NO}_{3}{ }^{-}$concentration, such as those draining agricultural catchments (Stanley and

552 Maxted 2008; Lassaletta et al. 2009) may have a limited capacity to retain excess $\mathrm{NO}_{3}{ }^{-}$.

553 On the other hand, biofilms developing in streams with low $\mathrm{NO}_{3}{ }^{-}: \mathrm{NH}_{4}{ }^{+}$ratios due to

554 inputs of $\mathrm{NH}_{4}{ }^{+}$-rich sources, such as streams receiving wastewater treatment plant

555 effluents (Marti et al. 2004; Martí et al. 2010), may show decreases in the capacity for

$556 \mathrm{NO}_{3}{ }^{-}$uptake. Biofilm responses to increases in the concentration of the DIN species,

557 which can be driven by land use changes, may have relevant implications for the export

558 of DIN to downstream ecosystems.

559 
561 We thank M. Martí and S. Pla for their field and laboratory assistance. We are also

562 grateful to the to the Font del Regàs landowners, Massaneda Garden and the Direcció

563 del Parc Natural del Montseny (Diputació de Barcelona) for allowing access to the

564 study sites during the experiments. This study was funded by the Spanish Ministry of

565 Education and Science through NICON project (ref: CGL2005-7362). MR was

566 supported by a contract with the Spanish Ministry of Science and Innovation through

567 the MED_FORSTREAM project (CGL2011-30590-C02-02). DvS's work was also

568 funded by a Juan de la Cierva postdoctoral contract (JCI-2010-06397) from the Spanish

569 Ministry of Science and Innovation.

570 
572 APHA (1995) Standard methods for the examination of water and wastewater. $19^{\text {th }}$ edn. American Public Health Association, Washington.

574

575

576

577

578

579

580

581

582

583

584

585

586

587

588

589

590

591

592

593

594

595

596

597

Battin TJ, Kaplan LA, Newbold JD, Hansen CME (2003) Contributions of microbial biofilms to ecosystem processes in stream mesocosms. Nature 426:439-442 doi:10.1038/nature02152

Bechtold HA, Marcarelli AM, Baxter CV, Inouye RS (2012) Effects of N, P, and organic carbon on stream biofilm nutrient limitation and uptake in a semi-arid watershed. Limnol Oceanogr 57:1544-1554 doi:10.4319/lo.2012.57.5.1544

Bernhardt ES, Hall RO, Likens GE (2002) Whole-system estimates of nitrification and nitrate uptake in streams of the Hubbard Brook Experimental Forest. Ecosystems 5:419-430 doi:10.1007/s10021-002-0179-4

Bernhardt ES, Likens GE (2004) Controls on periphyton biomass in heterotrophic streams. Freshw Biol 49:14-27 doi:10.1046/j.1365-2426.2003.01161.x

Bernot MJ, Tank JL, Royer TV, David MB (2006) Nutrient uptake in streams draining agricultural catchments of the midwestern United States. Freshw Biol 51:499509 doi:10.1111/j.1365-2427.2006.01508.x

Bunch ND, Bernot MJ (2012) Nitrate and ammonium uptake by natural stream sediment microbial communities in response to nutrient enrichment. Res Microbiol 163:137-141 doi:10.1016/j.resmic.2011.11.004

Camargo JA, Alonso A (2006) Ecological and toxicological effects of inorganic nitrogen pollution in aquatic ecosystems: A global assessment. Environ Int 32:831-849 doi:10.1016/j.envint.2006.05.002

Dodds WK, Lopez AJ, Bowden WB, Gregory S, Grimm NB, Hamilton SK, Hershey AE, Marti E, Mcdowell WH, Meyer JL, Morrall D, Mulholland PJ, Peterson BJ., Tank JL, Valett HM, Webster JR. \& Wollheim W (2002) N uptake as a function of concentration in streams. J N Am Benthol Soc 21:206-220 
Dodds WK, Marti E, Tank JL, Pontius J, Hamilton SK, Grimm NB, Bowden WB, Mcdowell WH, Peterson BJ, Valett HM, Webster JR, Gregory S (2004) Carbon and nitrogen stoichiometry and nitrogen cycling rates in streams. Oecologia 140:458-467 doi:10.1007/s00442-004-1599-y

Dodds WK, Welch EB (2000) Establishing nutrient criteria in streams. J N Am Benthol Soc 19:186-196

Domingues RB, Barbosa AB, Sommer U, Galvao HM (2011) Ammonium, nitrate and phytoplankton interactions in a freshwater tidal estuarine zone: potential effects of cultural eutrophication. Aquat Sci 73:331-343 doi:10.1007/s00027-011-01800

Dortch Q (1990) The interaction between ammonium and nitrate uptake in phytoplankton. mar ecol-prog ser 61:183-201 doi:10.3354/meps061183

Dugdale RC, Wilkerson FP, Hogue VE, Marchi A (2007) The role of ammonium and nitrate in spring bloom development in San Francisco Bay Estuar. Coast Shelf Sci 73:17-29 doi:10.1016/j.ecss.2006.12.008

Fellows CS, Valett HM, Dahm CN, Mulholland PJ, Thomas SA (2006) Coupling nutrient uptake and energy flow in headwater streams. Ecosystems 9:788-804 doi:10.1007/s10021-006-0005-5

Francoeur SN (2001) Meta-analysis of lotic nutrient amendment experiments: detecting and quantifying subtle responses. J N Am Benthol Soc 20:358-368 doi: $10.2307 / 1468034$

Geisseler D, Horwath WR, Joergensen RG, Ludwig B (2010) Pathways of nitrogen utilization by soil microorganisms - A review. Soil Biol Biochem 42:2058-2067 doi:10.1016/j.soilbio.2010.08.021

Gonzalez PJ, Correia C, Moura I, Brondino CD, Moura JJG (2006) Bacterial nitrate reductases: Molecular and biological aspects of nitrate reduction. J Inorg Biochem 100:1015-1023 doi:10.1016/j.jinorgbio.2005.11.024 
Gordon ND, McMahon TA, Finlayson BL (1992) Stream hydrology: an introduction for ecologists. Stream hydrology: an introduction for ecologists. John Wiley \& Sons,

Hill WR, Ryon MG, Schilling EM (1995) Light limitation in a stream ecosystem responses by primary producers and consumers. Ecology 76:1297-1309 doi:10.2307/1940936

Hoellein TJ, Tank JL, Kelly JJ, Rosi-Marshall EJ (2010) Seasonal variation in nutrient limitation of microbial biofilms colonizing organic and inorganic substrata in streams. Hydrobiologia 649:331-345 doi:10.1007/s10750-010-0276-x

Holmes RM, McClelland JW, Sigman DM, Fry B, Peterson BJ (1998) Measuring N-15$\mathrm{NH} 4+$ in marine, estuarine and fresh waters: An adaptation of the ammonia diffusion method for samples with low ammonium concentrations. Marine Chemistry 60:235-243

Johnson LT, Tank JL, Dodds WK (2009) The influence of land use on stream biofilm nutrient limitation across eight North American ecoregions Can J Fish Aquat Sci 66:1081-1094 doi:10.1139/f09-065

Keck F, Lepori F (2012) Can we predict nutrient limitation in streams and rivers? Freshw Biol 57:1410-1421 doi:10.1111/j.1365-2427.2012.02802.x

Kemp MJ, Dodds WK (2002) The influence of ammonium, nitrate, and dissolved oxygen concentrations on uptake, nitrification, and denitrification rates associated with prairie stream substrata. Limnol Oceanogr 47:1380-1393

King SA, Heffernan JB, Cohen MJ (2014) Nutrient flux, uptake, and autotrophic limitation in streams and rivers. Freshw Sci 33:85-98 doi:10.1086/674383

Lassaletta L, Garcia-Gomez H, Gimeno BS, Rovira JV (2009) Agriculture-induced increase in nitrate concentrations in stream waters of a large Mediterranean catchment over 25 years (1981-2005). Sci Total Environ 407:6034-6043 doi:10.1016/j.scitotenv.2009.08.002 
Marti E, Aumatell J, Gode L, Poch M, Sabater F (2004) Nutrient retention efficiency in streams receiving inputs from wastewater treatment plants. Journal of Environmental Quality 33:285-293

Martí E, Riera J, Sabater F (2010) Effects of Wastewater Treatment Plants on Stream Nutrient Dynamics Under Water Scarcity Conditions. In: Sabater S, Barceló D (eds) Water Scarcity in the Mediterranean, vol 8. The Handbook of Environmental Chemistry. Springer Berlin / Heidelberg, pp 173-195. doi:10.1007/698_2009_33

McCarty GW (1995) the role of glutamine-synthetase in regulation of nitrogenmetabolism within the soil microbial community plant and soil 170:141-147 doi:10.1007/bf02183062

McIntire CD, Gregory SV, Steinman AD, Lamberti GA (1996) Modeling benthic algal communities: an example from stream ecology. Algal ecology: freshwater benthic ecosystems. Academic Press. doi:10.1016/b978-012668450-6/50050-3

Merbt S, Auguet J-C, Blesa A, Martí E, Casamayor E (2015) Wastewater Treatment Plant Effluents Change Abundance and Composition of Ammonia-Oxidizing Microorganisms in Mediterranean Urban Stream Biofilms Microb Ecol 69:66-74 doi:10.1007/s00248-014-0464-8

Naldi M, Wheeler PA (2002) N-15 measurements of ammonium and nitrate uptake by Ulva fenestrata (chlorophyta) and Gracilaria pacifica (rhodophyta): Comparison of net nutrient disappearance, release of ammonium and nitrate, and N-15 accumulation in algal tissue. J Phycol 38:135-144 doi:10.1046/j.15298817.2002.01070.x

Newbold JD, Bott TL, Kaplan LA, Dow CL, Jackson JK, Aufdenkampe AK, Martin LA, Van Horn DJ, De Long AA (2006) Uptake of nutrients and organic C in streams in New York City drinking-water-supply watersheds. J N Am Benthol Soc 25:998-1017

O'Brien JM, Dodds WK (2008) Ammonium uptake and mineralization in prairie streams: chamber incubation and short-term nutrient addition experiments. Freshw Biol 53:102-112 doi:10.1111/j.1365-2427.2007.01870.x 
682

683

684

685

686

687

688

689

690

691

692

693

694

695

696

697

698

699

700

701

702

703

704

705

706

707

708

O'Brien JM, Dodds WK, Wilson KC, Murdock JN, Eichmiller J (2007) The saturation of N cycling in Central Plains streams: N-15 experiments across a broad gradient of nitrate concentrations. Biogeochemistry 84:31-49 doi:10.1007/s10533-007-9073-7

Pusch M et al. (1998) The role of micro-organisms in the ecological connectivity of running waters. Freshw Biol 40:453-495 doi:10.1046/j.1365-2427.1998.00372.x

Ribot M, von Schiller D, Peipoch M, Sabater F, Grimm NB, Marti E (2013) Influence of nitrate and ammonium availability on uptake kinetics of stream biofilms. Freshw Sci 32:1155-1167 doi:10.1899/12-209.1

Risgaard-Petersen N, Nicolaisen MH, Revsbech NP, Lomstein BA (2004) Competition between ammonia-oxidizing bacteria and benthic microalgae. Appl Environ Microbiol 70:5528-5537 doi:10.1128/aem.70.9.5528-5537.2004

Sabater F, Butturini A, Marti E, Munoz I, Romani A, Wray J, Sabater S (2000) Effects of riparian vegetation removal on nutrient retention in a Mediterranean stream. $\mathbf{J}$ N Am Benthol Soc 19:609-620 doi:10.2307/1468120

Sigman DM, Altabet MA, Michener R, McCorkle DC, Fry B, Holmes RM (1997) Natural abundance-level measurement of the nitrogen isotopic composition of oceanic nitrate: an adaptation of the ammonia diffusion method. Marine Chemistry 57:227-242

Stanley EH, Maxted JT (2008) Changes in the dissolved nitrogen pool across land cover gradients in Wisconsin streams. Ecol Appl 18:1579-1590 doi:10.1890/07-1379.1

Steinman AD (1996) Effects of grazers on freshwater benthic algae. Algal ecology: freshwater benthic ecosystems. doi:10.1016/b978-012668450-6/50041-2

Tank JL, Dodds WK (2003) Nutrient limitation of epilithic and epixylic biofilms in ten North American streams. Freshw Biol 48:1031-1049 doi:10.1046/j.13652427.2003.01067.x

von Schiller D, Marti E, Riera JL, Ribot M, Marks JC, Sabater F (2008) Influence of land use on stream ecosystem function in a Mediterranean catchment. Freshw Biol 53:2600-2612 doi:10.1111/j.1365-2427.2008.02059.x 
711 von Schiller D, Marti E, Riera JL, Sabater F (2007) Effects of nutrients and light on periphyton biomass and nitrogen uptake in Mediterranean streams with contrasting land uses. Freshw Biol 52:891-906 doi:10.1111/j.13652427.2007.01742.x

715

716

717

718

719

720

Zar JH (1996) Biostatistical analysis. $3^{\text {rd }}$ edition. Prentice-Hall, Upper Saddle River, New Jersey.

Zuur AF, Ieno EN, Walker NJ, Saveliev AA, Smith GM (2009) Mixed effects models and extensions in ecology with R (Statistics for biology and health). Springer Science+Business Media, LLC2009. 
721 Tables

722 Table 1. Physical and chemical characteristics of the streams in which the nutrient

723 diffusing substrata (NDS) were incubated.

\begin{tabular}{|c|c|c|c|c|c|}
\hline & Font del Regàs & Castanyet & $\begin{array}{c}\text { Santa Fe del } \\
\text { Montseny }\end{array}$ & Gualba & Santa Coloma \\
\hline Stream code & FR & CAS & MON & GUA & $\mathrm{COL}$ \\
\hline Forested area (\%) & 99.7 & 99.6 & 99.4 & 96.0 & 92.6 \\
\hline Urban area (\%) & 0.0 & 0.0 & 0.0 & 0.6 & 3.7 \\
\hline Agricultural area (\%) & 0.2 & 0.4 & 0.0 & 2.1 & 3.4 \\
\hline Longitude $2^{\circ} \mathrm{E}$ & $27^{\prime} 00^{\prime \prime}$ & $37^{\prime} 25^{\prime \prime}$ & $277^{\prime \prime}$ & $30 \prime 17 "$ & 39'32" \\
\hline Latitude $41^{\circ} \mathrm{N}$ & 49'32"' & $53^{\prime} 28^{\prime \prime}$ & $46^{\prime} 37^{\prime \prime}$ & $44^{\prime} 02^{\prime \prime}$ & $51^{\prime} 48 \prime$ \\
\hline Mean altitude $(\mathrm{m})$ & 429 & 572 & 1419 & 940 & 554 \\
\hline Discharge $\left(\mathrm{L} \mathrm{s}^{-1}\right)$ & $21.7 \pm 4.4$ & $2.5 \pm 1.4$ & $9.3 \pm 0.5$ & $11.2 \pm 3.1$ & $11.5 \pm 4.5$ \\
\hline Water temperature $\left({ }^{\circ} \mathrm{C}\right)$ & $16.6 \pm 0.4$ & $19.8 \pm 0.9$ & $14.2 \pm 0.8$ & $19.8 \pm 0.9$ & $21.4 \pm 1.0$ \\
\hline Conductivity $\left(\mu \mathrm{S} \mathrm{cm}^{-1}\right)$ & $198.0 \pm 3.2$ & $214.0 \pm 10$ & $60.6 \pm 0.4$ & $123.9 \pm 7.7$ & $309.7 \pm 8.8$ \\
\hline $\mathrm{NH}_{4}+\left(\mu \mathrm{g} \mathrm{N} \mathrm{L}^{-1}\right)$ & $14 \pm 3$ & $19 \pm 2$ & $16 \pm 3$ & $17 \pm 3$ & $22 \pm 1$ \\
\hline $\mathrm{NO}_{3}{ }^{-}+\mathrm{NO}_{2}{ }^{-}\left(\mu \mathrm{g} \mathrm{N} \mathrm{L}{ }^{-1}\right)$ & $144 \pm 33$ & $140 \pm 85$ & $189 \pm 23$ & $270 \pm 9$ & $600 \pm 263$ \\
\hline $\operatorname{SRP}\left(\mu g P^{-1}\right)$ & $4 \pm 1$ & $8 \pm 5$ & $20 \pm 2$ & $20 \pm 1$ & $46 \pm 39$ \\
\hline $\mathrm{NO}_{3}^{-:}: \mathrm{NH}_{4}{ }^{+}$ & $11.8 \pm 3.9$ & $8.0 \pm 5.5$ & $12.9 \pm 3.4$ & $16.5 \pm 2.6$ & $27.7 \pm 11.8$ \\
\hline DIN:SRP (molar) & $95.3 \pm 27.7$ & $50.3 \pm 6.4$ & $22.9 \pm 2.9$ & $32.3 \pm 1.8$ & $84.4 \pm 33.3$ \\
\hline
\end{tabular}

724 Data reported are the mean \pm SE of samples collected on three different dates during

725 each of the two NDS incubation periods $(n=6)$.

726 Note that streams are listed in order of increasing DIN availability (sum of $\mathrm{NH}_{4}{ }^{+}$and

$727 \mathrm{NO}_{3}{ }^{-}$concentrations).

728

729

730 
731 Table 2. Results from the linear mixed-effects model with stream as fixed factor and

732 incubation as random factor on the biomass accrual rate, algal accrual rate and C:N

733 molar ratio of biofilms in DIN-free treatments.

\begin{tabular}{lccc}
\hline \hline \multicolumn{1}{c}{ Variable } & $d f$ & $F$ & $p$ \\
\hline Biomass accrual rate & & & \\
$\quad$ Stream & 4 & 5.80 & $\begin{array}{c}<0.001 \\
\text { Incubation }\end{array}$ \\
Algal accrual rate & & & 0.922 \\
$\quad$ Stream & 4 & 14.64 & $<0.001$ \\
Incubation & & & 0.173 \\
C:N molar ratio & & & \\
Stream & 4 & 0.20 & 0.940 \\
Incubation & & & 0.664 \\
\hline
\end{tabular}

734 Significance of the random factor incubation was obtained with the Likelihood Ratio 735 Test.

736 Values highlighted in bold indicate significant effects $(p<0.05)$. 
749 Table 3. Results from the linear mixed-effects model with stream and NDS treatment as

750 fixed factors and incubation as random factor on biofilm growth response ratio (RR) to

751 DIN enrichments in the form of $\mathrm{NO}_{3}{ }^{-}$and $\mathrm{NH}_{4}{ }^{+}$among streams in terms of biomass

752 accrual rate, algal accrual rate and C:N molar ratio.

\begin{tabular}{lccc}
\hline \hline \multicolumn{1}{c}{ Variable } & $d f$ & $F$ & $p$ \\
\hline Biomass accrual rate & & & \\
Stream & 4 & 3.99 & $\mathbf{0 . 0 0 5}$ \\
Treatment & 1 & 0.06 & 0.813 \\
Stream x treatment & 4 & 0.75 & 0.558 \\
$\quad$ Incubation & & & 0.150 \\
Algal accrual rate & & & \\
Stream & 4 & 10.17 & $<0.001$ \\
Treatment & 1 & 13.85 & $<0.001$ \\
Stream x treatment & 4 & 2.00 & 0.101 \\
Incubation & & & 0.221 \\
C:N molar ratio & & & \\
Stream & 4 & 5.09 & $<0.001$ \\
Treatment & 1 & 0.50 & 0.483 \\
Stream x treatment & 4 & 0.88 & 0.480 \\
Incubation & & & 0.734 \\
\hline
\end{tabular}

753 Significance of the random factor incubation was obtained with the Likelihood Ratio

754 Test.

755 Values highlighted in bold indicate significant effects $(p<0.05)$

756

757

758 
759 Table 4. Results from two-way ANOVA with stream and NDS treatment as fixed

760 factors on biofilm uptake response ratio (RR) to DIN enrichments in the form of $\mathrm{NO}_{3}{ }^{-}$

761 and $\mathrm{NH}_{4}{ }^{+}$among streams in terms of biomass-specific uptake rate of $\mathrm{NO}_{3}{ }^{-}\left(U_{\text {spec }}-\mathrm{NO}_{3}{ }^{-}\right)$,

$762 \mathrm{NH}_{4}{ }^{+}\left(U_{\text {spec }}-\mathrm{NH}_{4}{ }^{+}\right)$and relative preference index (RPI).

\begin{tabular}{llccc}
\hline \hline & Variable & $d f$ & $F$ & $p$ \\
\hline$U_{\text {spec }}-\mathrm{NO}_{3}{ }^{-}$ & & & & \\
& Stream & 4 & 9.57 & $<\mathbf{0 . 0 0 1}$ \\
& Treatment & 1 & 58.13 & $<\mathbf{0 . 0 0 1}$ \\
& Stream x treatment & 4 & 6.12 & $<\mathbf{0 . 0 0 1}$ \\
$U_{\text {spec }}-\mathrm{NH}_{4}{ }^{+}$ & & & & \\
& Stream & 4 & 1.99 & 0.118 \\
& Treatment & 1 & 1.06 & 0.311 \\
& Stream x treatment & 4 & 1.92 & 0.129 \\
$\mathrm{RPI}$ & & & & \\
& Stream & 4 & 5.38 & $\mathbf{0 . 0 0 1}$ \\
& Treatment & 1 & 4.81 & $\mathbf{0 . 0 3 4}$ \\
& Stream x treatment & 4 & 2.30 & 0.075 \\
\hline
\end{tabular}

763 Values highlighted in bold indicate significant effects $(p<0.05)$.

764

765 


\section{Figure legends}

Figure 1. Biomass accrual rate (a), algal accrual rate (b) and $\mathrm{C}: \mathrm{N}$ molar ratio (c) of biofilms developed on nutrient diffusing substrata (NDS) for the different streams and nutrient treatments in which the NDS were incubated. Data reported are the mean $\pm \mathrm{SE}$.

Figure 2. Relationships between biofilm variables and ambient concentrations of $\mathrm{NO}_{3}{ }^{-}$ and $\mathrm{NH}_{4}{ }^{+}$in the streams in which the NDS were incubated. Biomass accrual rates and $\mathrm{NO}_{3}{ }^{-}$(a) or $\mathrm{NH}_{4}^{+}(\mathbf{b})$, algal accrual rates and $\mathrm{NO}_{3}{ }^{-}$(c) or $\mathrm{NH}_{4}{ }^{+}(\mathbf{d})$, and biomass-specific uptake for $\mathrm{NO}_{3}{ }^{-}\left(U_{\text {spec }}-\mathrm{NO}_{3}{ }^{-}\right)$and $\mathrm{NO}_{3}{ }^{-}(\mathbf{e})$ or $\mathrm{NH}_{4}{ }^{+}(\mathbf{f})$. Results are for Pearson correlations. Values highlighted in bold indicate significant correlations $(p<0.05)$.

Figure 3. Biomass-specific uptake for $\mathrm{NO}_{3}{ }^{-}\left(U_{\text {spec }}-\mathrm{NO}_{3}{ }^{-} ; \mathbf{a}\right)$, for $\mathrm{NH}_{4}{ }^{+}\left(U_{\text {spec }}-\mathrm{NH}_{4}{ }^{+} ; \mathbf{b}\right)$ and relative preference index (RPI; c) of biofilms developed on nutrient diffusing substrata (NDS) in the different streams and nutrient treatments. Note that the y-axis from panel $\mathbf{b}$ is one order of magnitude lower than that from panel $\mathbf{a}$. In panel $\mathbf{c}$, the horizontal dashed line at 1 denotes the shift from $\mathrm{NH}_{4}{ }^{+}$to $\mathrm{NO}_{3}{ }^{-}$preference. Values $<1$ indicate preference for $\mathrm{NH}_{4}{ }^{+}$, whereas values $>1$ indicate preference for $\mathrm{NO}_{3}{ }^{-}$. Data reported are the mean $\pm \mathrm{SE}$.

Figure 4. Biofilm growth response ratio (RR) to enrichments of $\mathrm{NO}_{3}{ }^{-}$and $\mathrm{NH}_{4}{ }^{+}$in terms of biomass accrual rate (a), algal accrual rate (b) and C:N molar ratio (c) for the different streams in which the nutrient diffusing substrata (NDS) were incubated. Data reported are the mean $\pm \mathrm{SE}$. 
Figure 5. Biofilm DIN uptake response ratio (RR) to enrichments of $\mathrm{NO}_{3}{ }^{-}$and $\mathrm{NH}_{4}{ }^{+}$in terms of biomass-specific uptake for $\mathrm{NO}_{3}{ }^{-}\left(U_{\text {spec }}-\mathrm{NO}_{3}{ }^{-} ; \mathbf{a}\right)$ and for $\mathrm{NH}_{4}{ }^{+}\left(U_{\text {spec }}-\mathrm{NH}_{4}{ }^{+} ; \mathbf{b}\right)$, and relative preference index (RPI; $\mathbf{c})$ for the different streams in which the nutrient diffusing substrata (NDS) were incubated. Data reported are the mean \pm SE. 
Figure 1
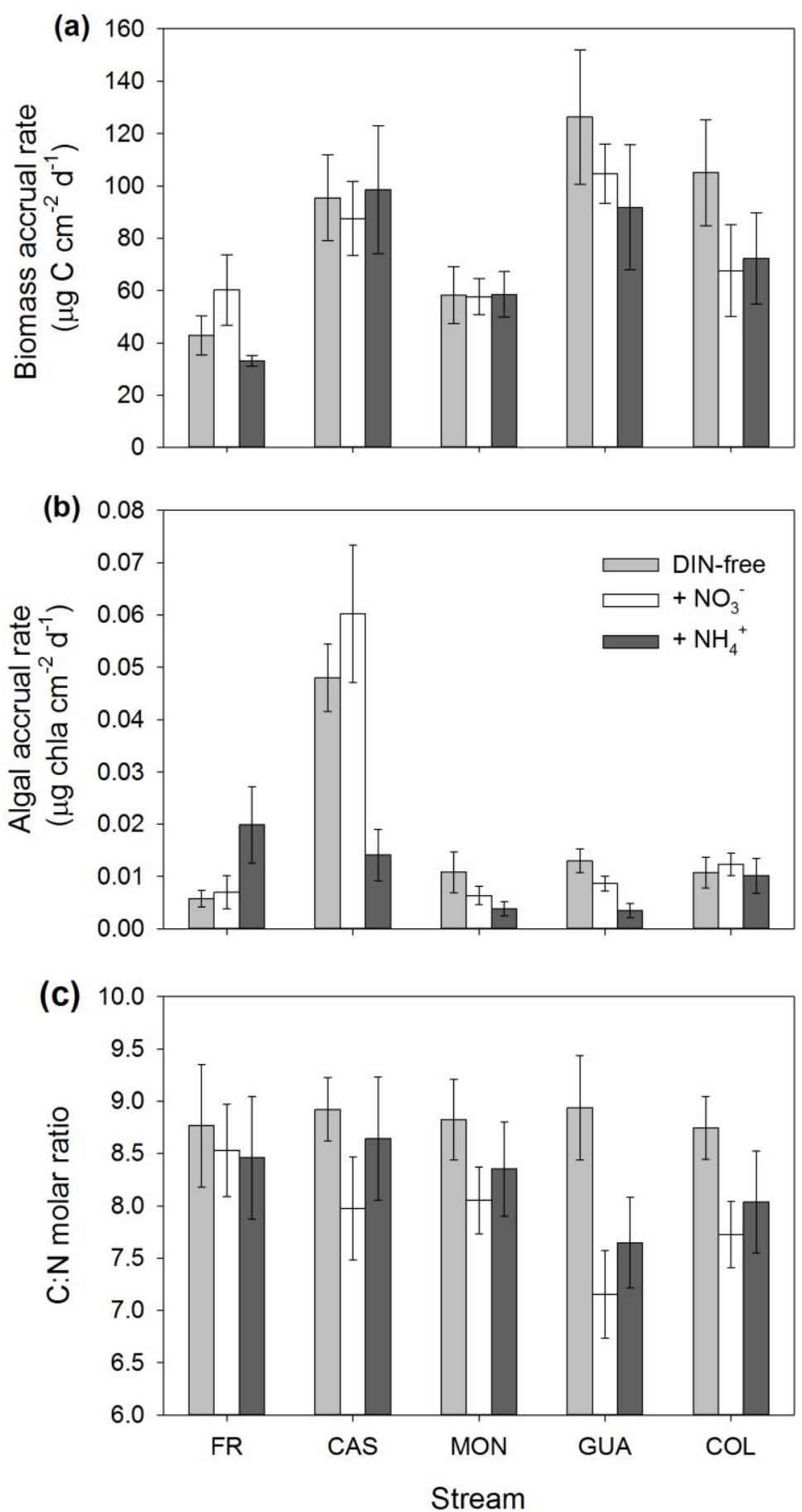
Figure 2
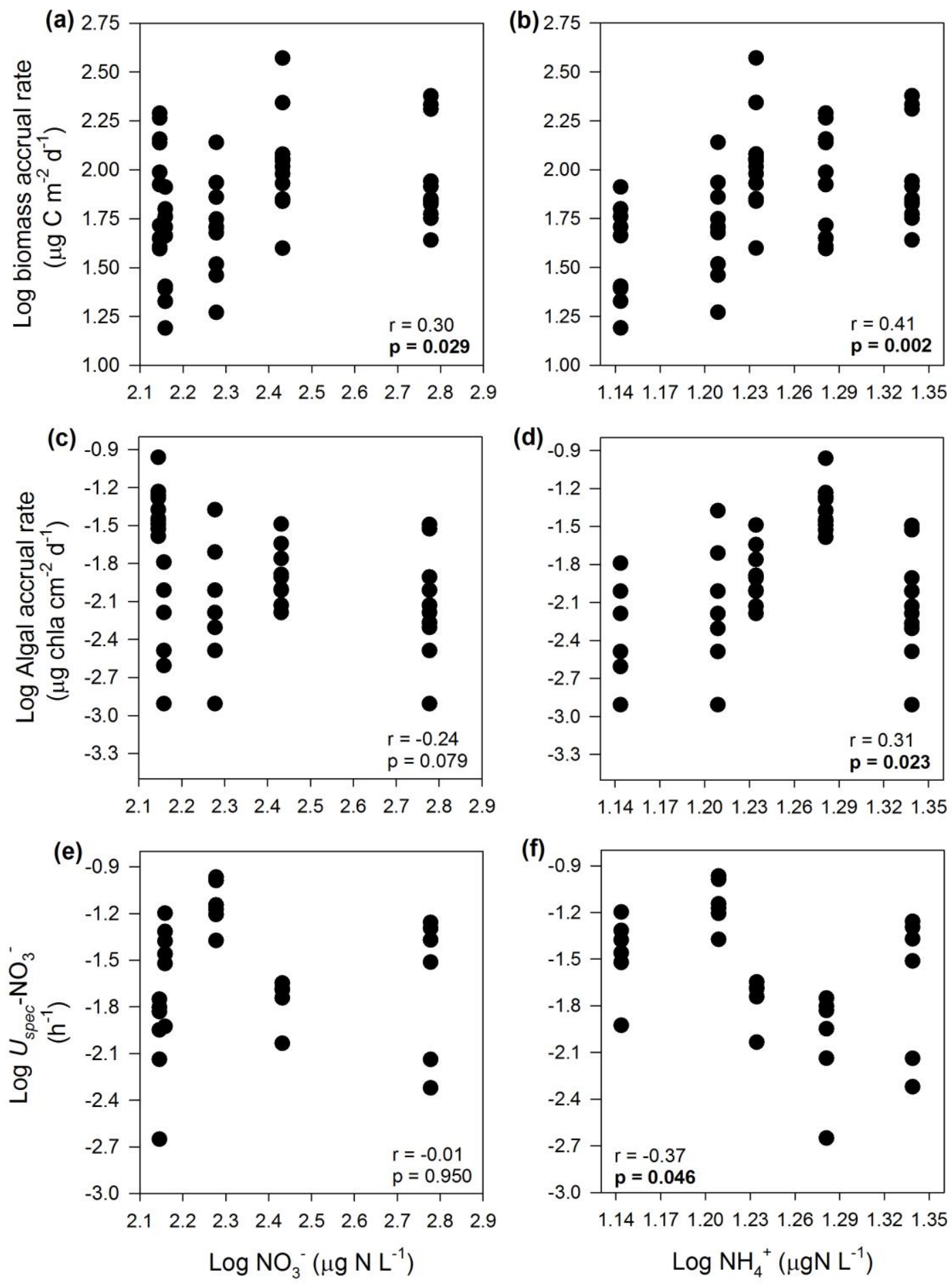
Figure 3
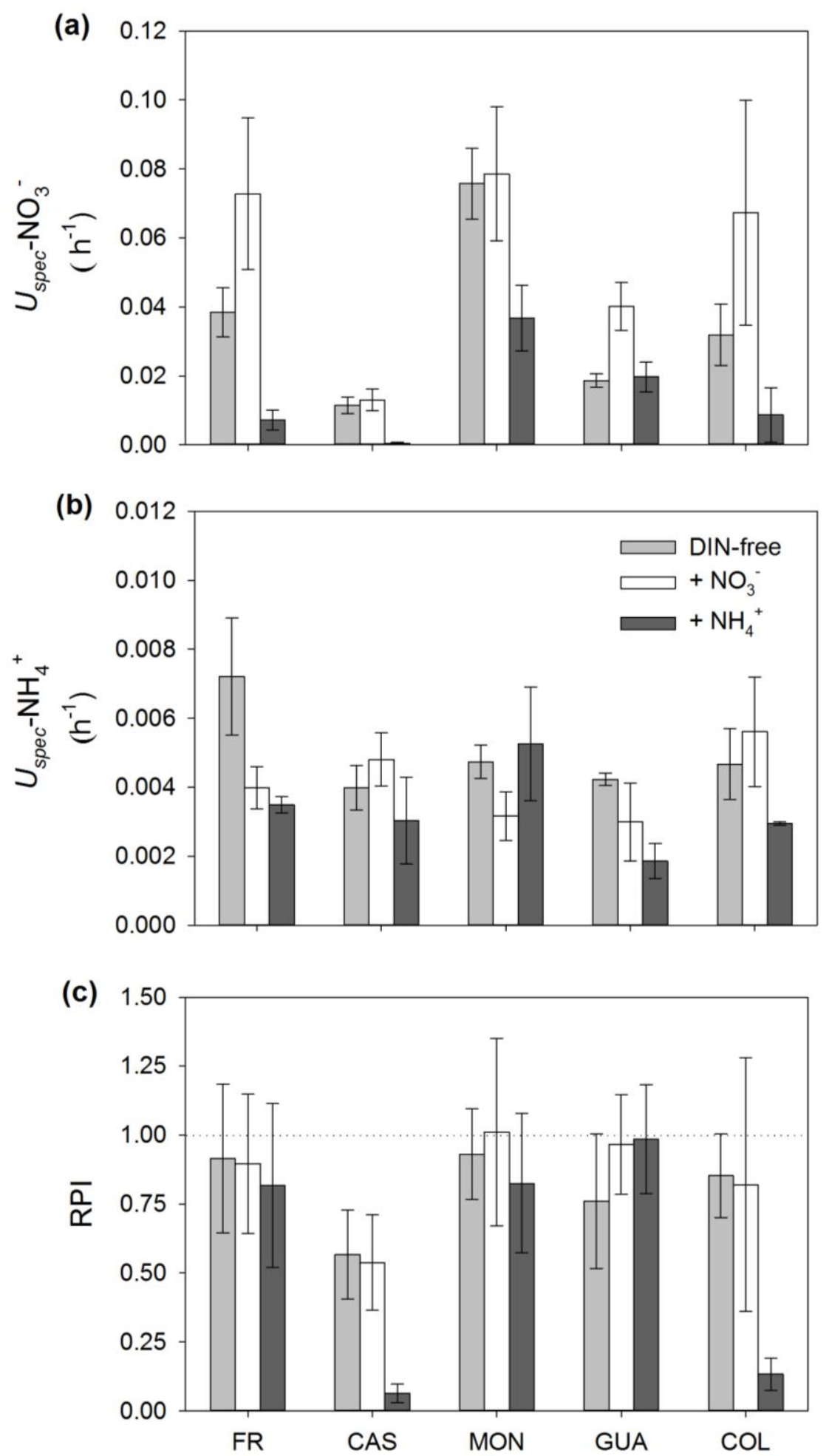
Figure 4
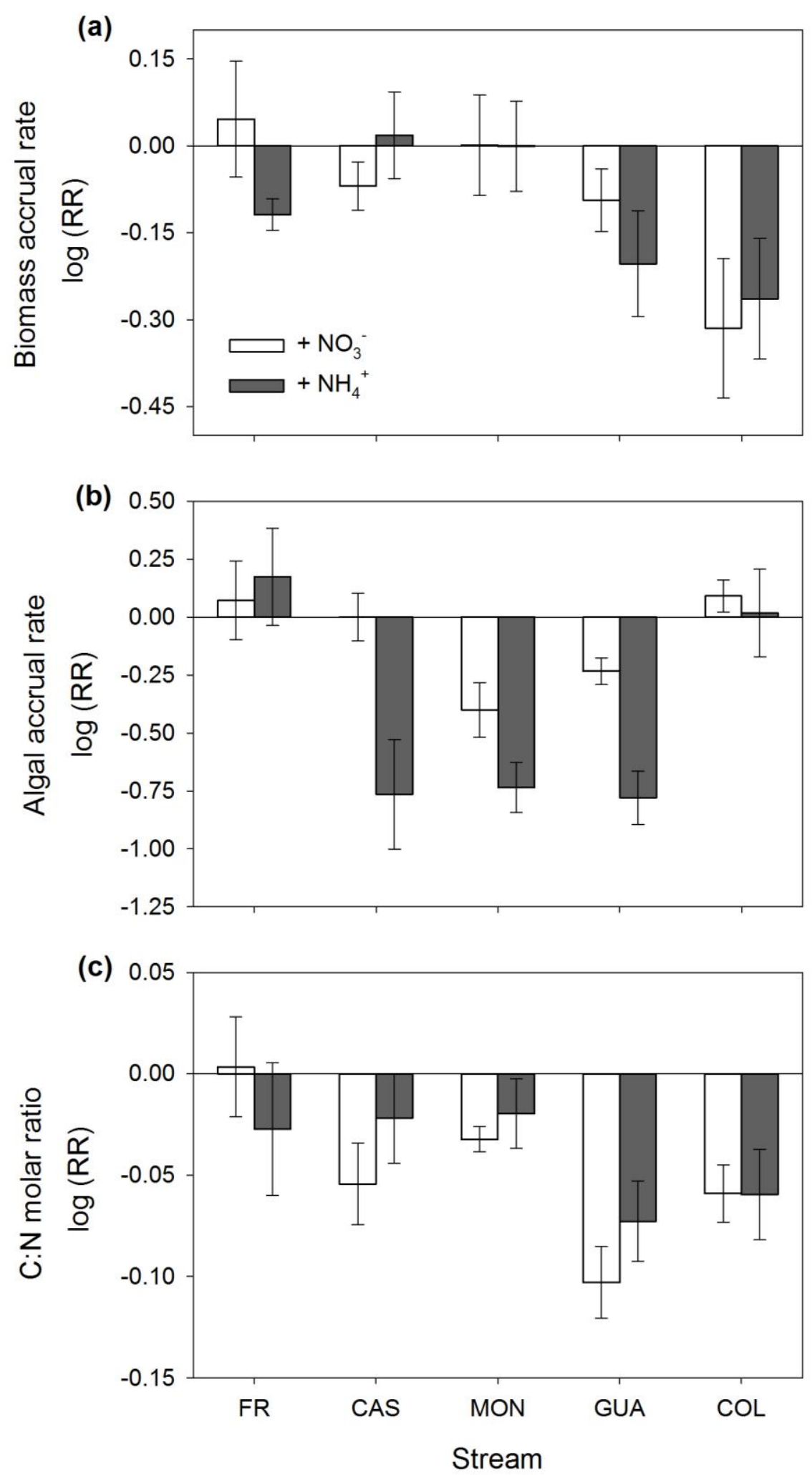
Figure 5
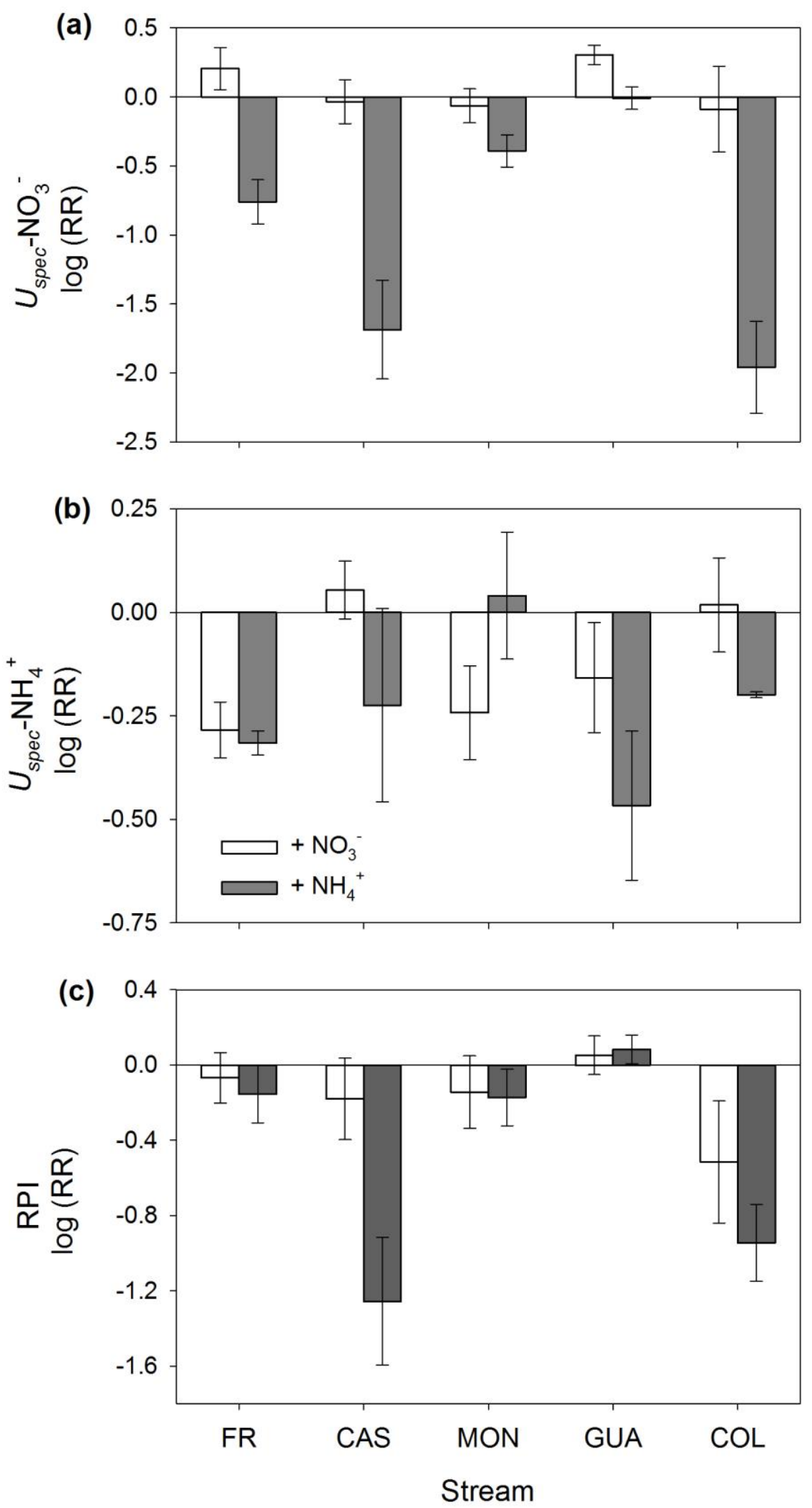